\title{
Do Morphological Similarities and human-induced dispersal explain the non-native occurrence of Serpulidae (Annelida) in Southwest Atlantic? Taxonomic detailing is the key
}

\author{
Andrielle Raposo Rodrigues ${ }^{1,3}$; Luis Felipe Skinner ${ }^{2}$ \& Ana Claudia dos Santos Brasil ${ }^{1,4}$ \\ ${ }^{1}$ Universidade Federal Rural do Rio de Janeiro (UFRRJ), Instituto de Ciências Biológicas e da Saúde (ICBS), Departamento de Biologia Animal, \\ Laboratório de Polychaeta. Seropédica, RJ, Brasil. \\ 2 Universidade do Estado do Rio de Janeiro (UERJ), Departamento de Ciências, Laboratório de Ecologia e Dinâmica Bêntica Marinha. \\ São Gonçalo, RJ Brasil. http://orcid.org/0000-0003-0971-4870. E-mail: Iskinner@uerj.br \\ 3 ORCID: http://orcid.org/0000-0001-9152-355X. E-mail: andriraposo@gmail.com (corresponding author) \\ ${ }^{4}$ ORCID: http://orcid.org/0000-0002-0611-9948. E-mail: acbrasil@gmail.com
}

\begin{abstract}
Species of Serpulidae are common on benthic and biofouling communities, occurring attached on both natural and artificial substrates. In this paper, Serpulids were collected from intertidal to subtidal areas, on rocky shore and suspended artificial plates in port areas. Herein we report three new records of serpulid species to the coast of Rio de Janeiro, Brazil. We also discuss the misidentification of Spirobranchus tetraceros, which was previously reported to the north of Rio de Janeiro.
\end{abstract}

Key-Words. Spirobranchus; Hydroides; Protula; Introduced species; Tropical West Atlantic.

\section{INTRODUCTION}

The Serpulidae is a family of filter-feeding tubiculous polychaetes with broad global distributions, occurring in virtually all marine environments throughout an extensive bathymetric gradient (Fitzhugh, 1989; Bastida-Zavala \& ten Hove, 2003; Sun et al., 2015). Their bodies are divided into a branchial crown, a thorax, and an abdomen (ten Hove \& Kupriyanova, 2009). Several species present distinct opercula that can vary considerably in shape, representing a useful morphological feature for differentiating species. Similarly, the different shapes and structures of their typically calcareous tubes have been used to diagnose species among distinctive genera (Bastida-Zavala \& Salazar-Vallejo, 2000; ten Hove \& Kupriyanova, 2009).

These polychaetes are encrusting organisms that colonise both natural (e.g., algae, shells, and corals) and artificial substrates (e.g., boat hulls, piers, floats, pillars, and solid residues) (Kiessling et al., 2015; Bastida-Zavala et al., 2017; Gündoğdu et al., 2017; Gracia et al., 2018). Their notable ability to attach themselves to many types of substrates and different surfaces, even moving objects such as ship hulls and floats, contributes to their passive transportation from one locality to another, with this colonisation ability perhaps responsible for their global invasiveness. Increasing polychaete abundances in different environments and on diverse substrates has prompted the need for expert identification of these species but, unfortunately, the lack of experienced taxonomists has resulted in ever increasing misidentifications (Rocha et al., 2013; Wong et al., 2014).

According to Çinar (2013), the Serpulidae accounts for $\sim 15 \%$ of all reported alien species worldwide, with the most speciose genus Hydroides among them. For example, Hydroides elegans (Haswell, 1883) has been reported as invasive in many areas across the globe (Schawn et al., 2016; Sun et al., 2018), as is Ficopomatus uschakovi (Pillai, 1960) that forms large reef-like aggregates (Assis et al., 2008; Bastida-Zavala \& GarciaMadrigal, 2012). These two species have become established as exotics in Brazil, being frequently found along the coast and usually occurring in high densities on hard substrates.

Rates of exotic species introductions in different oceans have been increasing over the last three decades, probably reflecting the greater 
intensity of anthropogenic activities such as shipping and aquaculture (Carlton, 1989; Ruiz et al., 2000; Neves \& Rocha, 2008). The use of sheltered harbors worldwide has increased connectivity among biogeographical regions (Clarke et al., 2004; Lopes, 2009; Castro et al., 2017) and greatly contributes to colonisation by several non-native species. Once biogeographical barriers have been overcome, regional or local transportation is considered crucial for further spread of exotic species (Kauano et al., 2017; Pelletier-Rousseau et al., 2019). Only recently has this topic received attention from local legislatures and in international treaties to control the spread of marine species (Clarke et al., 2004; Lopes, 2009; Rocha et al., 2013; Tricarico et al., 2016; Castro et al., 2017).

A first step in controlling the spread of marine species worldwide and increasing our knowledge of this threat was the 2000-2004 GloBallast Programme (LealNeto \& Jablonski, 2004; Tricarico et al., 2016), in which Brazil was a partner country. This program prompted the International Maritime Organization (IMO) to establish ballast water controls to prevent species transfer among regions (Clarke et al., 2004; Tricarico et al., 2016). Lopes (2009) listed for the first time the known invasive species in Brazilian marine waters. Rocha et al. (2013) highlighted the importance of taxonomic experts in elaborating lists of introduced species. A recent paper on exotic species identification in Brazil promotes collaboration between ecologists and taxonomists (Oricchio et al., 2019).

Here, we discuss the distributions of certain polychaete species occurring in the densest area of ports along the central coast of Brazil and its nearby regions, based on accurate taxonomic identifications and descriptions of these species. We confirm the establishment of Spirobranchus tetraceros (Schmarda, 1861) in Brazil. This species was first reported in Brazil by Skinner et al. (2012), but those authors misidentified it as S. giganteus (Pallas, 1766), a mistake previously identified by Perry et al. (2017). We also report new occurrences of another two non-native species, i.e., Hydroides dianthus (Verrill, 1873) and Protula balboensis Monro, 1933. We discuss the global distributions of these species and their possible invasiveness along the Brazilian coast and in the Southwest Atlantic.

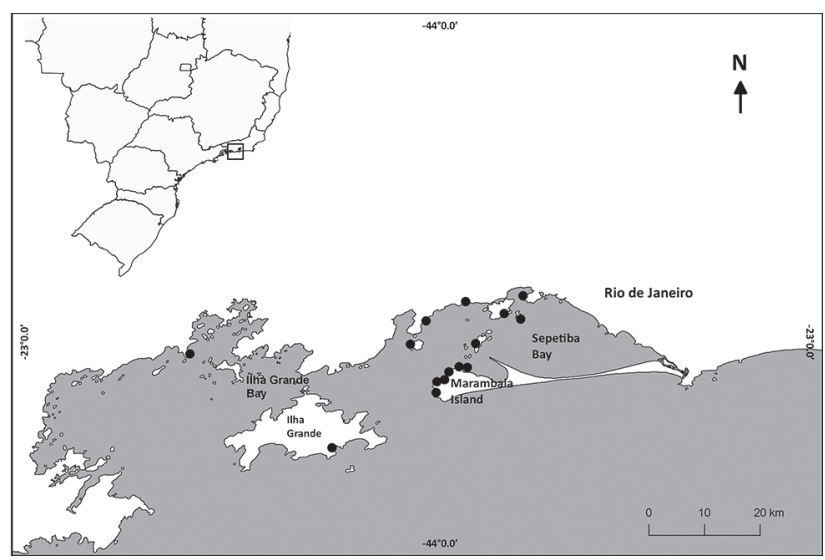

Figure 1. Distribution of the sampling locations at Sepetiba Bay, Ilha Grande and Marambaia Island in the Rio de Janeiro coast.

\section{MATERIAL AND METHODS}

We sampled the intertidal and subtidal region in several localities of Sepetiba Bay $\left(22^{\circ} 54^{\prime}-23^{\circ} 04^{\prime} \mathrm{S}\right.$, $43^{\circ} 34^{\prime}-44^{\circ} 10^{\prime} \mathrm{W}$ ) and in the subtidal area at Ilha Grande $\left(22^{\circ} 50^{\prime}-23^{\circ} 20^{\prime} \mathrm{S}, 44^{\circ} 00^{\prime}-44^{\circ} 45^{\prime} \mathrm{W}\right)$ totalizing 15 different locations as indicated in Fig. 1. In this area there are five large harbors and one shipyard, all of them dealing with ships coming from different areas of the globe (Clarke et al., 2004; Lopes, 2009; Castro et al., 2017). This region has also the highest number of marinas and recreational boats on South America (Skinner et al., 2016) that helps to create suitable environments for fouling species, and to help its spread.

The polychaetes were collected actively from natural substrates and also, from artificial substrates made of plastic, PVC and granite plates. After being removed alive from the substrate with their tubes, they were anesthetized and euthanized in seawater with Menthol, then fixed in $10 \%$ formalin and transferred for permanent preservation in $70 \%$ ethanol. All specimens resulted from these surveys are deposited in the Polychaeta collection at Museu Nacional, Rio de Janeiro, MNRJP (Universidade Federal do Rio de Janeiro, Brazil).

The identification of the specimens was performed using the relevant literature (ten Hove, 1970; ten Hove \& Kupriyanova, 2009; Bastida-Zavala, 2009). The generic determination was based mainly on the morphology of both the operculum and tubes. For species determination, permanent slides of chaetae were prepared using Hoyer's mounting media (Krantz, 1978). The specimens were photographed and measured using Leica M205C binocular microscope, using LAS software to perform multi-focus images. The measurements of the individuals were obtained dorsally and followed: total length (distance from the anterior end of operculum to the end of pygidium), thoracic length, thoracic width $\left(4^{\text {th }}\right.$ thoracic chaetigerous between the two parapodia), abdominal length, peduncle length (peduncle length plus basal plate of the operculum), operculum width (lateral axis), diameter of the operculum (dorsal-ventral axis). In all individuals, the number of radioles by crown lobe was counted, as well as the abdominal segments. Measurements were expressed in millimeters.

\section{RESULTS}

\section{Family SERPULIDAE Rafinesque, 1815 Genus Spirobranchus Blainville, 1817 Spirobranchus tetraceros (Schmarda, 1861)}

(Figs. 2-4)

Pomatoceros tetraceros Schmarda, 1861: p. 30; Taf. XXI, fig. 179.

Spirobranchus tetraceros: ten Hove, 1970: p. 3-14; figs. 1-6; 7-14; 15-22; 23-27. Ben-Eliahu \& ten Hove, 2011: p. 88-94; fig. 33A-E; table 5. Kupriyanova et al., 2015: p. 337-339; fig. 30C-D. 
Examined material: 199 specimens. Rio de Janeiro State, Mangaratiba Municipality: Ilha de Itacuruçá: $22^{\circ} 56^{\prime} 58.6^{\prime \prime} \mathrm{S}$, 4353'13.4"W, MNRJP2184 (105 specimens). Ilha dos Martins: $22^{\circ} 57^{\prime} 17.0^{\prime \prime} \mathrm{S}, 43^{\circ} 51^{\prime} 39.2^{\prime \prime} \mathrm{W}$ (3 specimens). Ilha de Jaguanum: $23^{\circ} 00^{\prime} 08.8^{\prime \prime} \mathrm{S}, 43^{\circ} 56^{\prime} 14.4^{\prime \prime} \mathrm{W}$ (6 specimens). Ilha Guaíba: $23^{\circ} 00^{\prime} 13.1^{\prime \prime} \mathrm{S}, 4^{\circ} 03^{\prime} 07.9^{\prime \prime} \mathrm{W}$ (1 specimen). Mangaratiba: $22^{\circ} 58^{\prime} 57.1^{\prime \prime} \mathrm{S}, 44^{\circ} 03^{\prime} 04.7^{\prime \prime} \mathrm{W}$ (2 specimens). Praia de Muriqui: $22^{\circ} 55^{\prime} 43.4^{\prime \prime} \mathrm{S}, 4^{\circ} 57^{\prime} 17.9^{\prime \prime} \mathrm{W}$ (10 spec-

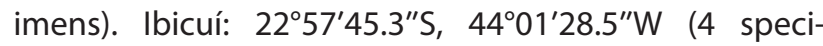
mens). Ilha da Marambaia: Praia de João Emanuel: $23^{\circ} 02^{\prime} 35.4^{\prime \prime} \mathrm{S}, 43^{\circ} 57^{\prime} 42.0^{\prime \prime} \mathrm{W}$ (7 specimens). Praia da Armação: $23^{\circ} 02^{\prime} 39.9^{\prime \prime} \mathrm{S}, 43^{\circ} 57^{\prime} 06.6^{\prime \prime} \mathrm{W}$ (10 specimens). Praia Suja: $23^{\circ} 03^{\prime} 57.2^{\prime \prime} \mathrm{S}, 43^{\circ} 59^{\prime} 31.3^{\prime \prime} \mathrm{W}$ (21 specimens). Praia Grande: $23^{\circ} 03^{\prime} 57.5^{\prime \prime} \mathrm{S}, 43^{\circ} 59^{\prime} 32.2^{\prime \prime} \mathrm{W}$ (4 specimens).

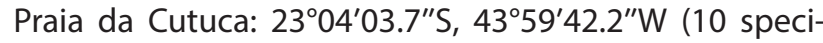
mens). Rio de Janeiro State, Itaguaí Municipality: Ilha da Madeira: $22^{\circ} 55^{\prime} 06.3^{\prime \prime} \mathrm{S}, 43^{\circ} 51^{\prime} 14.3^{\prime \prime} \mathrm{W}$ (16 specimens). Rio de Janeiro State, Angra dos Reis municipality: Piraquara: $23^{\circ} 01^{\prime} 14.0^{\prime \prime} \mathrm{S}, 44^{\circ} 26^{\prime} 245^{\prime \prime} \mathrm{W}$ (8 specimens). Dois Rios: $23^{\circ} 11^{\prime} 08.0^{\prime \prime} \mathrm{S}, 44^{\circ} 11^{\prime} 24.4^{\prime \prime} \mathrm{W}$ (2 specimens).

\section{Description (based on 10 individuals collected from Itacuruçá Island and Marambaia Island, Brazil)}

Tube: Externally white/light pink and sometimes violet in smaller tubes, inside light pink (Fig. 2A). Subtriangular in cross-section, with a single prominent wavy median and longitudinal ridge, laterally with fine transverse growth markings, lacking alveoli and peristomes (Fig. 2A). Anterior end with a fine tooth extending over the opening (Fig. 2A). Attached to rocky shores, Perna perna (Linnaeus, 1758) mussels and artificial substrates, such as PVC plates.

Radiolar crown: Radioles arranged in a circle on each side, with 18 radioles per lobe. Inter-radiolar membrane extending to about $1 / 3$ of radiolar length, smooth and bearing external rounded processes (Fig. 2B). Internally,

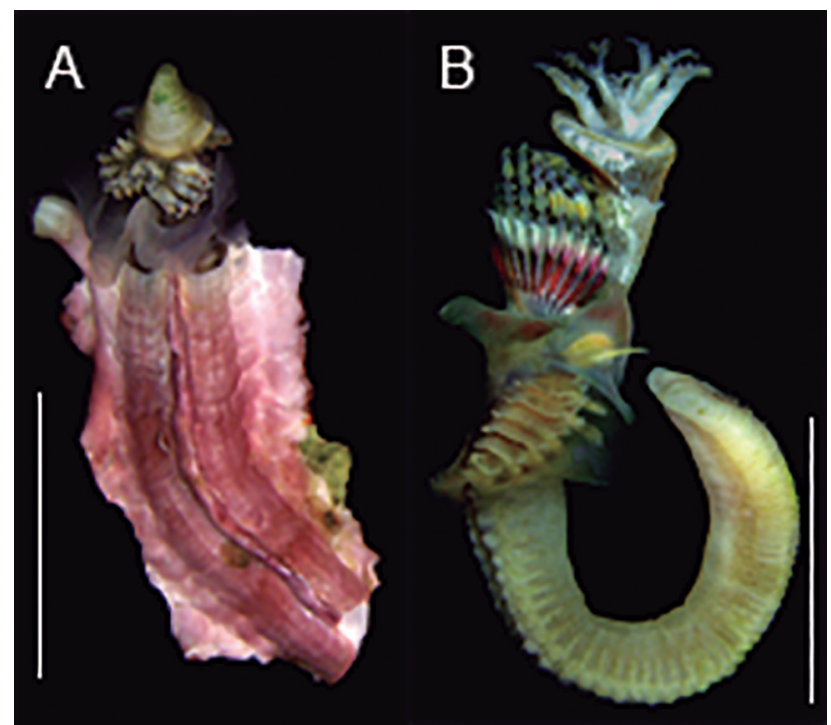

Figure 2. Spirobranchus tetraceros. (A) Tube with longitudinal ridge and projection in the anterior part of the tube; (B) Complete body, lateral view. Scale bars: A-B: $2 \mathrm{~mm}$. radioles with two rows of pinnules of the same length. Terminal filament without pinnules. Stylodes absent. Eyespots absent. In live specimens, the bases of radioles (including the inter-radiolar membrane) exhibit a mix of black/pink/yellow/white pigments (Figs. 2B, 3A, C-D). In fixed specimens, the radiolar crown has blue pigments (Fig. 3B).

Peduncle: Smooth, inserted left of the radiolar crown, near the medial line; dark pigments with irregular darker stripes on the dorsal side (Fig. 3); fixed specimens with blue pigments. Proximal area smooth and with narrow stem; distal area flattened and with a broad stem below the opercular plate (Fig. 3). Peduncle color extends into lateral wings. Pair of peduncular wings fringed with digitate processes (Fig. 3). Length: mean $=1.12(\mathrm{SD}=0.38$; $\mathrm{n}=10)$.

Operculum: Four distinct morphotypes, all with a circular calcareous opercular plate (Fig. 3). Type A: distal end of operculum conical and with concentric striations, without spines (Fig. 3A). Type B: initial bifurcation of short non-ramified spines that share the same base and lack spinules, with two spines lying dorso-lateral and a third ventral to the top of the opercular plate (Fig. 3B). Type C: four spines, but a group of three shares the same base; two of which are dorso-lateral, larger and forked once, a third is ventral, smaller and also forked once; spines with spinules at their tips and not divided to the opercular plate (Fig. 3C). Type D: similar to type C, but the spines are developed totally and exhibit more ramifications at their tips than other types, spinules present. Dorso-lateral spines ramified three or two times, ventral spine ramified twice (Fig. 3D). Spines white. Diameter: mean $=0.7$ $(S D=0.16 ; n=10)$; Width: mean $=0.71(S D=0.18 ; n=10)$.

Collar and thoracic membranes: Collar well-developed (Figs. 2B, 3C), covering $1 / 2$ of the radiolar crown, divided into one ventral and two lateral lobes of the same size. Ventral lobe triangular. Tonguelet present, dark in colour (black) between ventral and latero-dorsal lobes. Laterodorsal lobes extend to thoracic membranes, producing a short ventral apron. Two types of collar chaetae: 1) limbate or 2) bayonet-like with many small teeth at the base of the 'blade' (Fig. 4A). Collar and thoracic membranes light brown in colour (Fig. 3C).

Thorax: Seven chaetigers, six of which are uncinigerous (Fig. 2B); collar fascicle without row of uncini. Thoracic chaetae limbate and of two different sizes (Fig. 4B). Uncini saw-shaped, with 9-10 teeth and including an anterior-most gouge-shaped peg tooth (Fig. 4D).

Abdomen: Number of abdominal chaetigers varies from 32 to 71 (mean $=49.9 ; S D=15.93 ; n=10)$. Chaetae trumpet-shaped (Fig. 4C). Uncini saw-shaped, with 10-12 teeth and including gouge-shaped peg tooth (Fig. 4E).

Measurements: Total length: mean $=5.4(\mathrm{SD}=2.0$; $\mathrm{n}=10)$; Thoracic length: mean $=1.24(\mathrm{SD}=0.36$; 
$\mathrm{n}=10)$; Thoracic width: mean $=0.64(\mathrm{SD}=0.27 ; \mathrm{n}=10)$; Abdominal length: mean $=2.6(S D=1.35 ; n=10)$.

Remarks: Two species of Spirobranchus have been reported for the Brazilian coast (Amaral et al., 2013), Spirobranchus giganteus (Pallas, 1766) and Spirobranchus minutus (Rioja, 1941). Both of these species are readily discernible from our collected specimens, identified herein as $\mathrm{S}$. tetraceros.

The radioles of the radiolar crown in S. giganteus are spirally arranged, and the wings of the penduncle form a smooth inverted triangle (ten Hove, 1970). In contrast, the radioles of the radiolar crowns of our specimens are circularly arranged and the wings of the penduncle are fringed. The opercula of our specimens also differ from those of S. giganteus. The opercular spines of S. giganteus (two large ones, as well as other smaller ones) are ramified. The opercula of our specimens present four basic shapes (Fig. 3), varying from conical to a flat disc, and with three spines (one ventral and two lateral) sharing the same base (Fig. 3D).

Spirobranchus minutus has three longitudinal ridges and alveoli at the base of the tube (Rioja, 1941), unlike S. tetraceros, that has serrated ridges along the tube forming a tip without alveoli. Moreover, S. minutus has a triangular opercular penduncle with narrow and pointed wings (Zibrowius, 1970), whereas that of S. tetraceros is fringed with digitate wings. The operculum of S. minutus is globose, almost transparent, extends over a calcified plate (Zibrowius, 1970), and lacks spines.

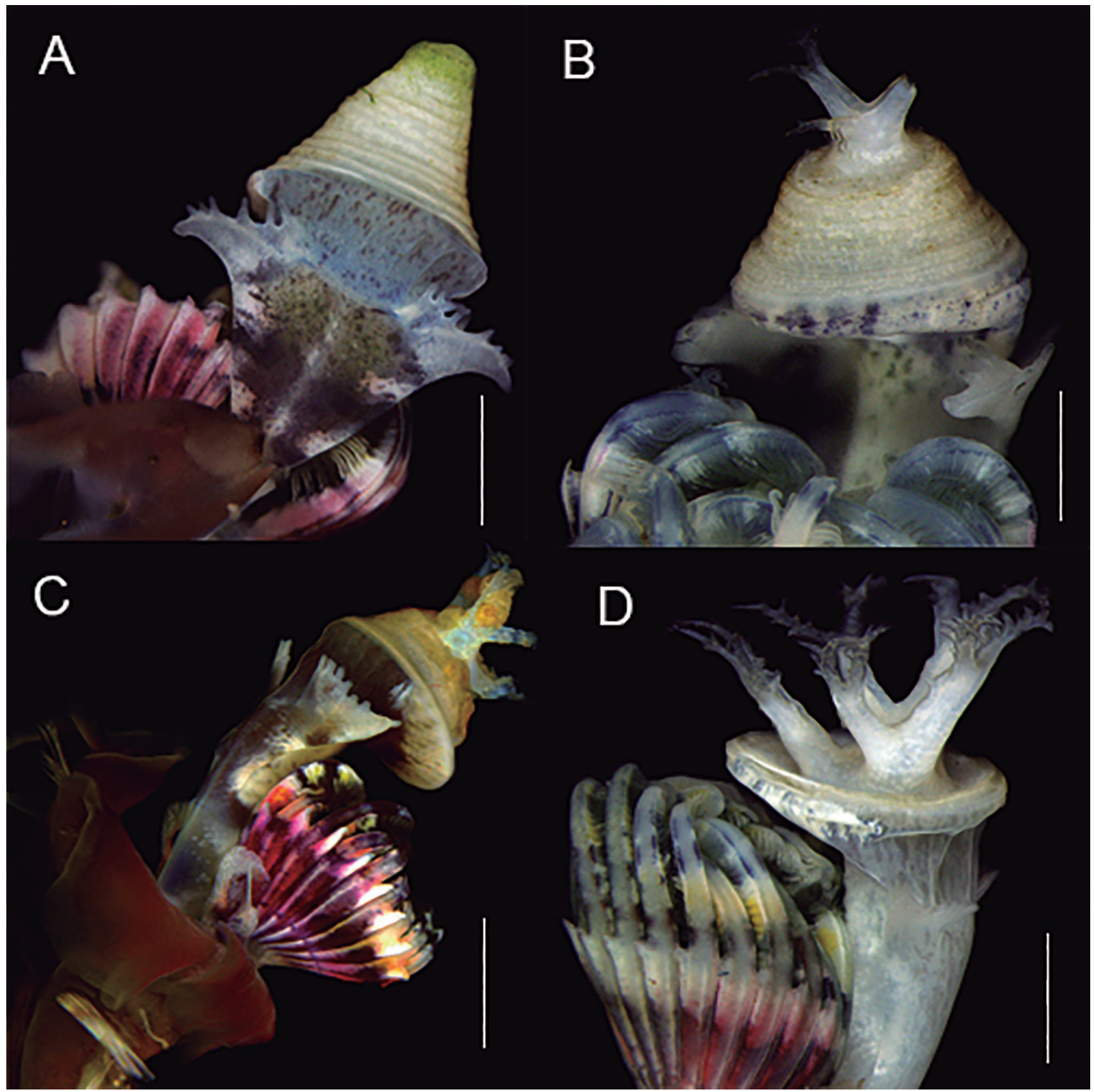

Figure 3. Spirobranchus tetraceros, operculum morphotypes. (A) Conical operculum, latero-dorsal view; (B) Initial bifurcation of operculum, dorsal view; (C) Bihorned operculum, latero-dorsal view; (D) Bi-horned operculum, lateral view. Scale bars: A-D: $500 \mu \mathrm{m}$. 
The species of Spirobranchus that occur in Curaçao (Caribbean Sea) were reviewed by ten Hove (1970), resulting in 22 taxa synonymized under the name S. tetraceros. However, Bastida-Zavala \& Salazar-Vallejo (2000) re-elevated Spirobranchus dendropoma (Mörch, 1863) to the species level based on their Mexican Caribbean material, distinguishing it from $\mathrm{S}$. tetraceros based on morphological and biogeographical differences (Perry et al., 2018). In their analyses of the material collected from the Mexican Caribbean, Bastida-Zavala \& Salazar-Vallejo (2000) observed that their specimens were morphologically more similar to S. dendropoma than to S. tetraceros, and also considered biogeographic information in identifying the species. Herein, we consider morphological characters for our specimens identifications, including the position of processes extending from the radiolar membrane. These processes occur at the bases of the radioles in S. dendropoma (Benedict, 1887; ten Hove, 1970). In our examined specimens of $S$. tetraceros, the interadiolar membrane processes occur between radioles and present a rounded shape.

Spirobranchus tetraceros was originally described from New South Wales in Australia (Schmarda, 1861), but it has also been recorded in the Red Sea (Perry et al., 2017), Mediterranean Sea, Hong Kong (Sun et al., 2012), Egypt, the Persian Gulf, and Curaçao (ten Hove, 1970). This species was first recorded in Brazil at Arraial do Cabo (Skinner et al., 2012), and herein we expand its distribution to Sepetiba Bay and Ilha Grande, both of which are in the southeast of the country.

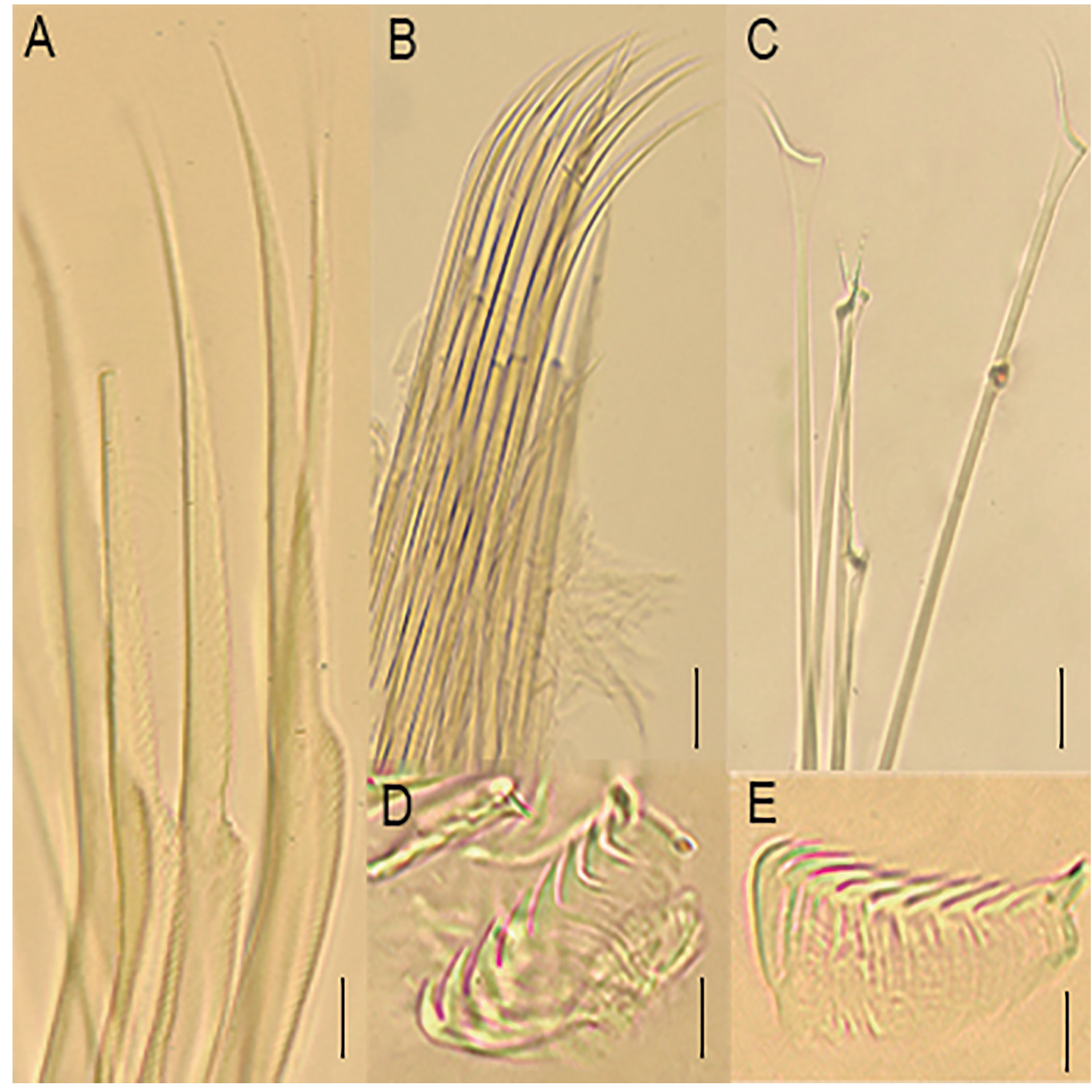

Figure 4. Spirobranchus tetraceros, types of chaetae. (A) Collar chaetae; bayonet chaetae, with tip processes; (B) Thoracic chaetae; limbate; (C) Abdominal chaetae; chaetae trumpet-shaped; (D) Uncini thoracic with 8 teeth; (E) Uncini abdominal with 11 teeth. Scale bars: A-E: $500 \mu \mathrm{m}$. 
Habitat: The species were found attached to rocky shores, Perna perna mussels and artificial substrates, such as PVC plates in subtidal areas.

Type-locality: New South Wales, Australia.

Distribution: West Pacific Ocean: Philippines; Port Jackson; Pandanon; Ubay; West Indian Ocean: Tanzania; Mozambique; Madagascar; Central Indian Ocean: Pearl Banks of Ceylon; Sri Lankan; Red Sea: Gulf of Aqaba; Red Sea; Djiboutian part of the Gulf of Aden; Persian Gulf; Mediterranean Sea; Lebanese part of the Mediterranean Sea; Greece; West Atlantic Ocean: Gulf of Mexico; Colombia (Read, 2018b); Brazil, at Arraial do Cabo, misidentified as S. giganteus, see Perry et al., 2017, Sepetiba Bay and Ilha Grande Bay (current work).

\section{Genus Hydroides Gunnerus, 1768 Hydroides dianthus (Verrill, 1873)} (Figs. 5 and 6)

Serpula dianthus Verril, 1873: p. 620.

Serpula dianthus var. citrine: Verril, 1873: p. 620-621.

Hydroides dianthus: Bastida-Zavala \& ten Hove, 2002: p. 143-147; figs. 23A-M, 24A-K, 28; Bastida-Zavala et al., 2017: p. 25-28; figs. 4C, 5.

Examined material: 70 specimens. Rio de Janeiro State, Mangaratiba Municipality: Praia de Ibicuí: $22^{\circ} 57^{\prime} 45.3^{\prime \prime}$,

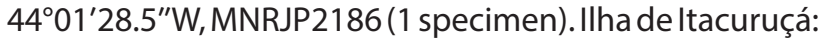
$22^{\circ} 56^{\prime} 58.6^{\prime \prime} \mathrm{S}, 43^{\circ} 53^{\prime} 13.4^{\prime \prime} \mathrm{W}, \mathrm{MNRJP} 2185$ (18 specimens). Praia de Muriqui: $22^{\circ} 55^{\prime} 43.4^{\prime \prime} \mathrm{S}, 4^{\circ} 57^{\prime} 17.9^{\prime \prime} \mathrm{W}$ (9 specimens). Ilha dos Martins: $22^{\circ} 57^{\prime} 17.0^{\prime \prime} \mathrm{S}, 43^{\circ} 51^{\prime} 39.2^{\prime \prime} \mathrm{W}$ (11 specimens). Ilha de Jaguanum: $23^{\circ} 00^{\prime} 08.8^{\prime \prime} S$, $43^{\circ} 56^{\prime} 14.4^{\prime \prime} \mathrm{W}$ (1 specimen). Rio de Janeiro State, Itaguaí Municipality: Ilha da Madeira: $22^{\circ} 55^{\prime} 06.3^{\prime \prime} \mathrm{S}, 43^{\circ} 51^{\prime} 14.3^{\prime \prime} \mathrm{W}$ (31 specimens).

\section{Description (based on 10 individuals collected from Madeira Island and Muriqui)}

Tube: Tube white both internally and externally (Fig. 5A), and circular in cross-section. Without longitudinal ridge, laterally with fine transverse growth markings (Fig. 5A); alveoli and peristomes absent. Attached to rocky shores, mollusc shells and artificial substrates such as PVC plates.

Radiolar crown: Radioles arranged in semi-circles, with 14-16 radioles per lobe (Fig. 5C). Inter-radiolar membrane absent. External side of radioles smooth, internal side with two rows of pinnules of the same length (Fig. 5C). Terminal filament without pinnules. Stylodes absent. Eyespots absent. Base of radiolar crown exhibits a mixture of orange and yellow pigments, together with alternating bands of dark brown and white (Fig. 5C). In fixed animals, color is light yellow.

Peduncle: Cylindrical, but with a constriction ill-defined at the distal end (Fig. 5B); proximal part a smooth nar- row stem. Penduncle inserted left side. Pseudoperculum present, smaller, rudimentary and inserted right side. Length: mean $=1.2(S D=0.26 ; n=10)$.

Operculum: Bioperculated (Fig. 5B); funnel-shaped base with 30-33 radii and a pointed tip; verticil with 10 amber-coloured spines, four dorsal spines curving towards internal face of verticil; ventral spines smaller and with spinules on their external faces (Fig. 5B), without central tooth; without internal and lateral spinules. Diameter: mean $=0.33(S D=0.08 ; n=10)$; Width: mean $=0.33$ $(S D=0.06 ; n=10)$.

Collar and thoracic membranes: Tri-lobed, subdivided into one medio-ventral and two lateral lobes (Fig. 5C). Tonguelet absent. Latero-dorsal lobes extend to thoracic membranes with a short ventral apron. Two types of chaetae: limbate or bayonet-like with two blunt elongate teeth, distal blade smooth (Fig. 6A).

Thorax: Seven chaetigers, six of which are uncinigerous; collar fascicle without row of uncini. Chaetae limbate (Fig. 6B), with two different sizes; uncini saw-shaped with 8-10 teeth including a gouge-shaped peg tooth (Fig. 6C).

Abdomen: Total number of chaetigers varies from 31 to 83 (mean $=56 ;$ SD $=16.9 ; n=10$ ). Chaetae of anterior and mid-abdominal chaetigers trumpet-shaped; uncini saw-shaped, with 6-8 teeth including a gouge-shaped peg tooth (Fig. 6D). Posterior chaetigers with capillary chaetae.

Measurements: Total length: mean $=6.2(\mathrm{SD}=1.35$; $\mathrm{n}=10)$; Thoracic length: mean $=1.3(\mathrm{SD}=0.34 ; \mathrm{n}=10)$; Thoracic width: mean $=0.57(S D=0.14 ; \mathrm{n}=10)$; Abdominal length: mean $=3.8(S D=1.2 ; n=10)$.

Remarks: There are 92 described species for the genus Hydroides (Sun et al., 2015), 13 of which have already been reported the Brazilian coast: $H$. brachyacantha Rioja, 1941; H. cruciger Mörch, 1863; $H$. dianthus; $H$. dirampha Mörch, 1863; H. elegans; H. gairacensis Augener, 1934; H. norvegica Gunnerus, 1768; H. parvus (Treadwell, 1902); H. plateni (Kinberg, 1867); H. sanctaecrucis Krøyer in Mörch, 1863; H. similoides Bastida-Zavala \& ten Hove, 2002; H. lambecki Bastida-Zavala \& ten Hove, 2002; and H. uncinata (Philippi, 1844) (Zibrowius, 1970; Amaral et al., 2013; Schawn et al., 2016).

Among those, only $H$. sanctaecrucis could possibly be confused with $H$. dianthus, by the presence of the ventrally curved spines at verticil. However, external spinules are present on the spines of $H$. sanctaecrucis, wich are lacking in $H$. dianthus (Bastida-Zavala \& ten Hove, 2002). All 10 verticil spines of $H$. dianthus are smooth, with four larger dorsal spines, and six smaller ventrally (BastidaZavala \& ten Hove, 2002; Lewis et al., 2006).

Hydroides dianthus was originally described for the eastern coast of the United States and from Cape Cod (Connecticut). The species occurs in eastern USA, northern Gulf of Mexico, Curaçao, along the Atlantic coasts of 
Europe and western Africa, Mediterranean Sea (BastidaZavala \& ten Hove, 2002), and at Cabo Frio (Rio de Janeiro State) in Brazil (Sun et al., 2017). Here we include the occurrence of $\mathrm{H}$. dianthus in Sepetiba Bay (Rio de Janeiro State), with specimens collected in the intertidal zone, growing on rocks, gastropods, and piers, and co-occurring with other species of the same genus.

Habitat: The species were found attached to rocky shores, mollusc shells and artificial substrates such as PVC plates.
Type-locality: Connecticut (Great Egg Harbor to New Haven and Cape (od), USA.

Distribution: West Pacific Ocean: Japan (Otani \& Yamanishi, 2010; Link et al., 2009); North Atlantic Ocean: Spain (Zibrowius, 1983); United Kingdom (Otani \& Yamanishi, 2010; Link et al., 2009); France (Dauvin et al., 2003); Belgium; Mediterranean: Mediterranean (Zenetos et al., 2005; Zenetos et al., 2010); Adriatic Sea; Italy (Marchini et al., 2015; Corriero et al., 2016); Turkey (Trott, 2004); Greece (Otani \& Yamanishi 2010; Link
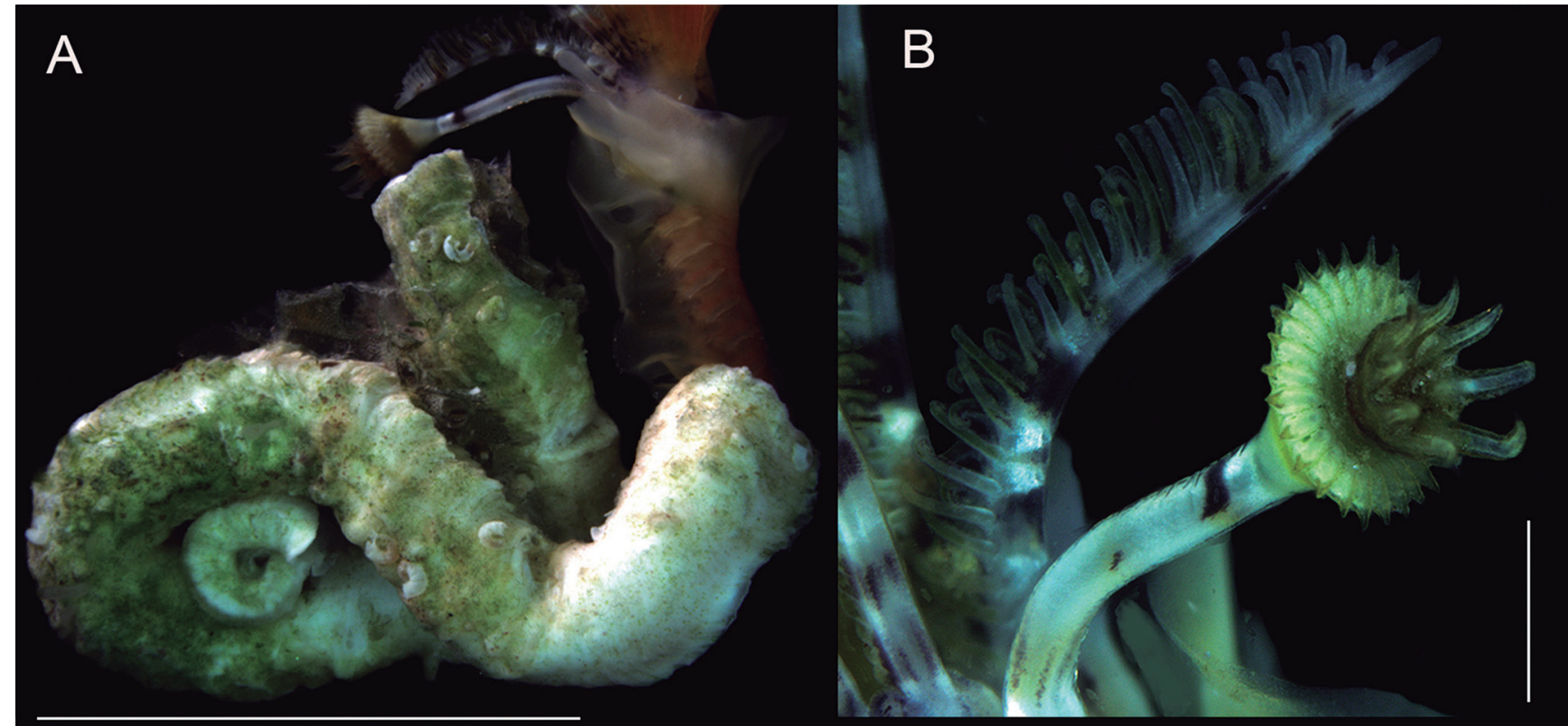

C

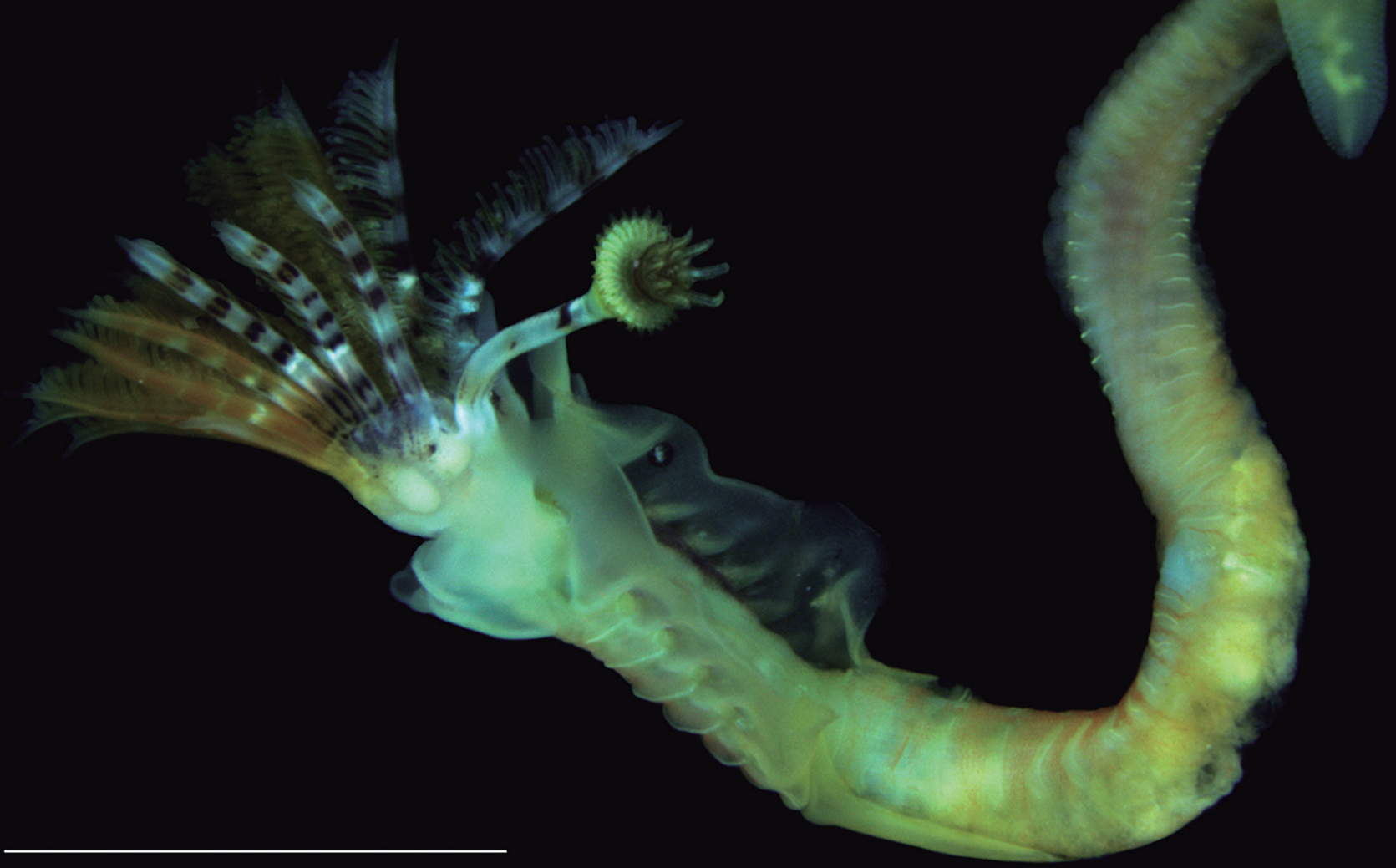

Figure 5. Hydroides dianthus. (A) Tube; (B) Operculum detail; (C) Complete body, dorso-lateral view. Scale bars: A and C: 2 mm; B: $500 \mu \mathrm{m}$. 
et al., 2009); East Atlantic Ocean: Gulf of Guinea (Dauvin et al., 2003; Read, 2018a); West Atlantic Ocean, United States: Cobscook Bay (Trott, 2004); Gulf of Maine (Otani \& Yamanishi, 2010; Link et al., 2009); Massachusetts (Marchini et al., 2015; Corriero et al., 2016); Narragansett Bay, Rhode Island; Chesapeake Bay, Virginia; Charleston, South Carolina; Jacksonville, Indian River, Biscayne Bay, Tampa Bay and Pensacola Bay, Florida; and Galveston Bay and Corpus Christi, Texas (Bastida-Zavala et al., 2017); Mexican Caribbean (Read, 2018a); West Atlantic Ocean: Cabo Frio, Brazil (Sun et al., 2017), Sepetiba Bay (current work).

\section{Genus Protula Risso, 1826 \\ Protula balboensis Monro, 1933 (Figs. 7 and 8)}

Protula tubularia balboensis Monro, 1933: p. 1088-1090; text-figure 30, A-D.

Protula balboensis: Zibrowius, 1970: p. 17-18; pl. 4; fig. 9; Bastida-Zavala, 2008: p. 37; fig. 8H; Bastida-Zavala et al., 2017: p. 42-43; figs. 7B-E, 8.

Examined material: 28 specimens. Rio de Janeiro State, Mangaratiba Municipality: Ilha da Madeira: Praia do Sino: $23^{\circ} 05^{\prime} 01.7^{\prime \prime} \mathrm{S}, 44^{\circ} 00^{\prime} 27.9^{\prime \prime} \mathrm{W}, \mathrm{MNRJP} 2187$ (22 specimens). Praia de Ibicuí: $22^{\circ} 57^{\prime} 45.3^{\prime \prime} \mathrm{S}, 4^{\circ} 01^{\prime} 28.5^{\prime \prime} \mathrm{W}$ (3 specimens). Ilha de Itacuruçá: 2256'58.6"S, 4353'13.4"W
(2 specimens). Ilha Guaíba: $23^{\circ} 00^{\prime} 13.1^{\prime \prime} \mathrm{S}, 44^{\circ} 03^{\prime} 07.9^{\prime \prime} \mathrm{W}$ (1 specimen).

\section{Description (based on 10 individuals collected from Marambaia Island)}

Tube: Externally, white and rugose, inside white (Fig. 7C); circular in cross-section. Without longitudinal ridge, alveoli and peristomes. Attached to rocky shores of intertidal zone.

Radiolar crown: Radioles arranged in semi-circles with 18-20 radioles per lobe (Fig. 7A). External side smooth, internal side with two rows of pinnules. Terminal filament without pinnules. Inter-radiolar membrane $1 / 3$ of radioles length, with rounded processes at end of membrane (Fig. 7B). Stylodes absent. Eyespots present, pigmented with red or yellow colours. Colour base in live animals a mixture of orange/yellow pigments, in fixed animals a light yellow.

Peduncle: Absent.

\section{Operculum: Absent.}

Collar and thoracic membranes: Trilobed, well-developed, reddish thoracic membrane in live, subdivided into one mid-ventral and two lateral lobes, the same size (Fig. 7A). Tonguelet absent. Latero-dorsal lobes continuing in thoracic membranes well-developed producing a

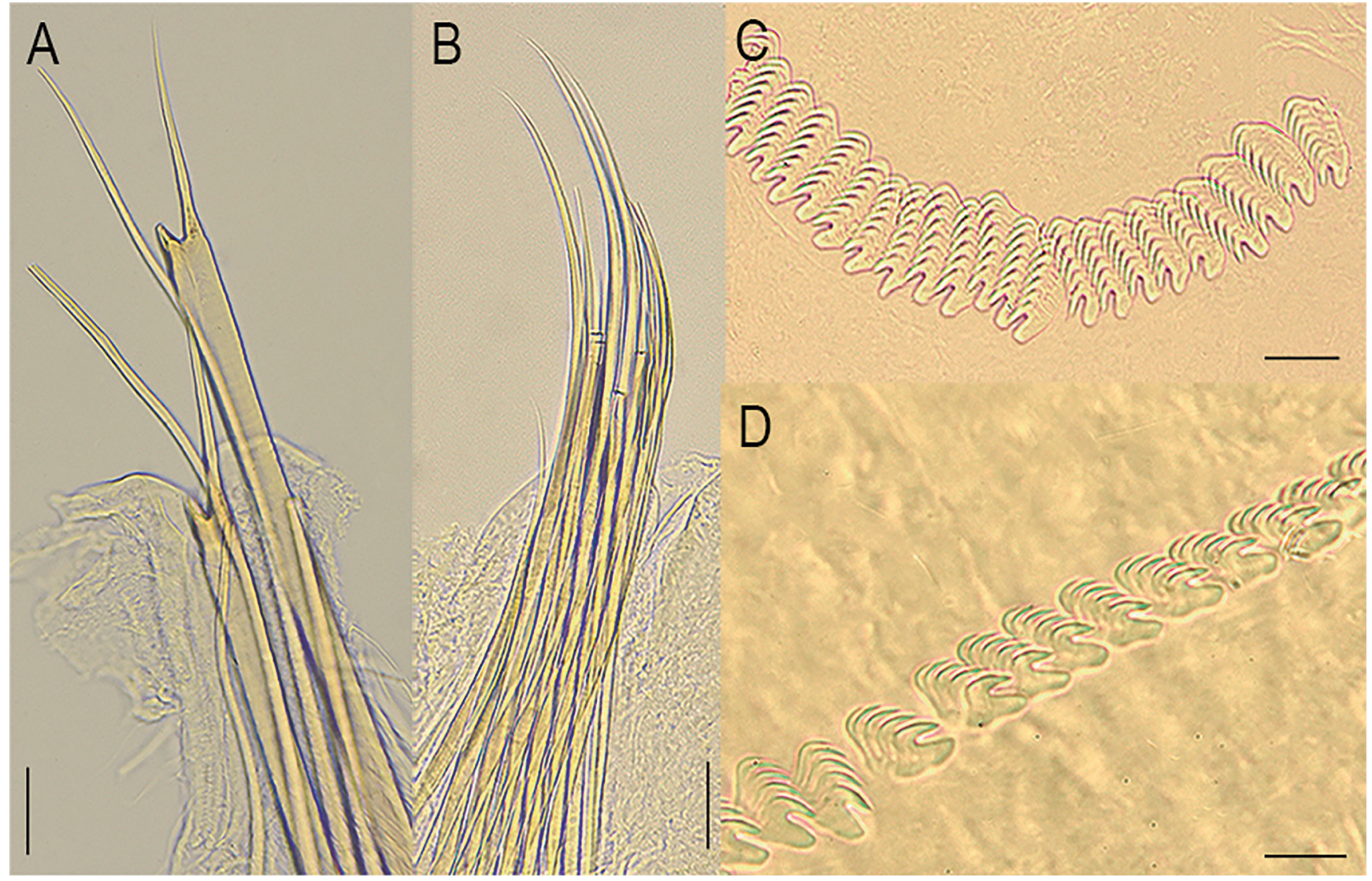

Figure 6. Hydroides dianthus, types of chaetae. (A) Collar chaetae; bayonet chateae with rounded process; (B) Thoracic chaetae; limbate; (C) Uncini thoracic with 8 teeth; (D) Uncini abdominal with 6 teeth. Scale bars: A-D: $500 \mu \mathrm{m}$. 
short ventral apron. Collar chaetae of only one type: limbate (Fig. 8A).

Thorax: Seven chaetigers, including five uncinigerous; collar fascicle without row of uncini. Second chaetiger with chaetae limbate, without uncini. Chaetae limbate of 2 sizes (Fig. 8B). Uncini rasp-shaped teeth including peg; peg (anterior-most tooth) gouge shaped. Apomatus chaetae absent.

Abdomen: Total number of chaetigers varies from 26 to 42 (mean $=37 ;$ SD $=5.7 ; n=10$ ). Anterior and mid-ab-

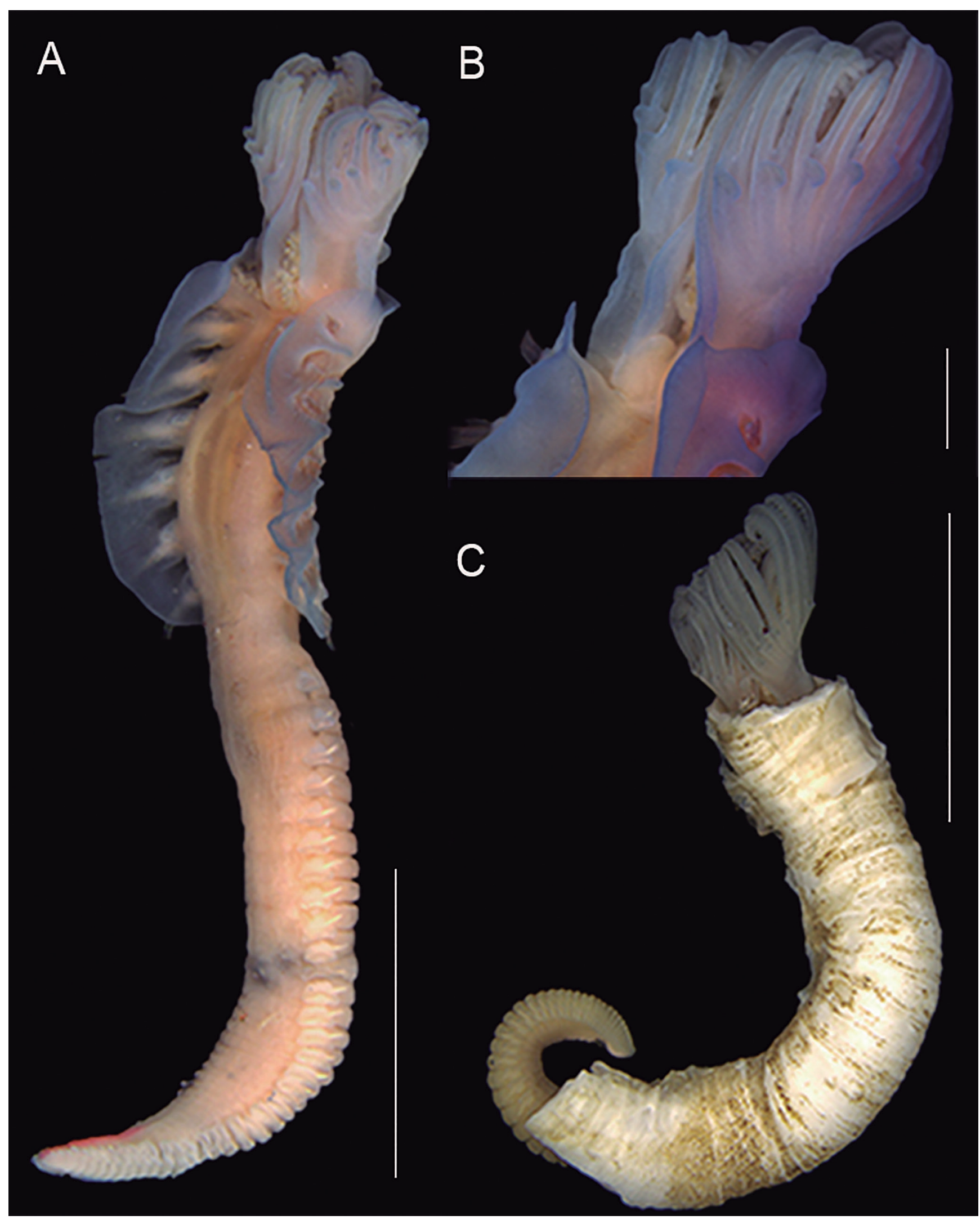

Figure 7. Protula balboensis. (A) Complete body, lateral view; (B) Branchial crown; (C) Tube with a worm inside. Scale bars: A and C: 2 mm; B: $500 \mu \mathrm{m}$. 
dominal chaetigers, chaetae geniculate (Fig. 8C); abdominal uncini similar to thoracic uncini. Posterior chaetigers with capillary chaetae.

Measurements: Total lenght: mean $=4.2(S D=1.4$; $\mathrm{n}=10)$; Thoracic lenght: mean $=1.4(\mathrm{SD}=0.45[\mathrm{n}=10])$; Thoracic width: mean $=0.54(\mathrm{SD}=0.16 ; \mathrm{n}=10)$. Abdominal lenght: mean $=2.2(S D=0.87 ; n=10)$.
Remarks: Twenty-three species of Protula are known from across the globe (ten Hove \& Kupriyanova, 2009), of which only three have been recorded from the Brazilian coast: P. tubularia (Montagu, 1803), P. submedia Augener, 1906, and P. balboensis (Amaral et al., 2013; Pagliosa et al., 2014).

Protula tubularia and P. balboensis are similar in having limbate thoracic chaetae and geniculate abdominal

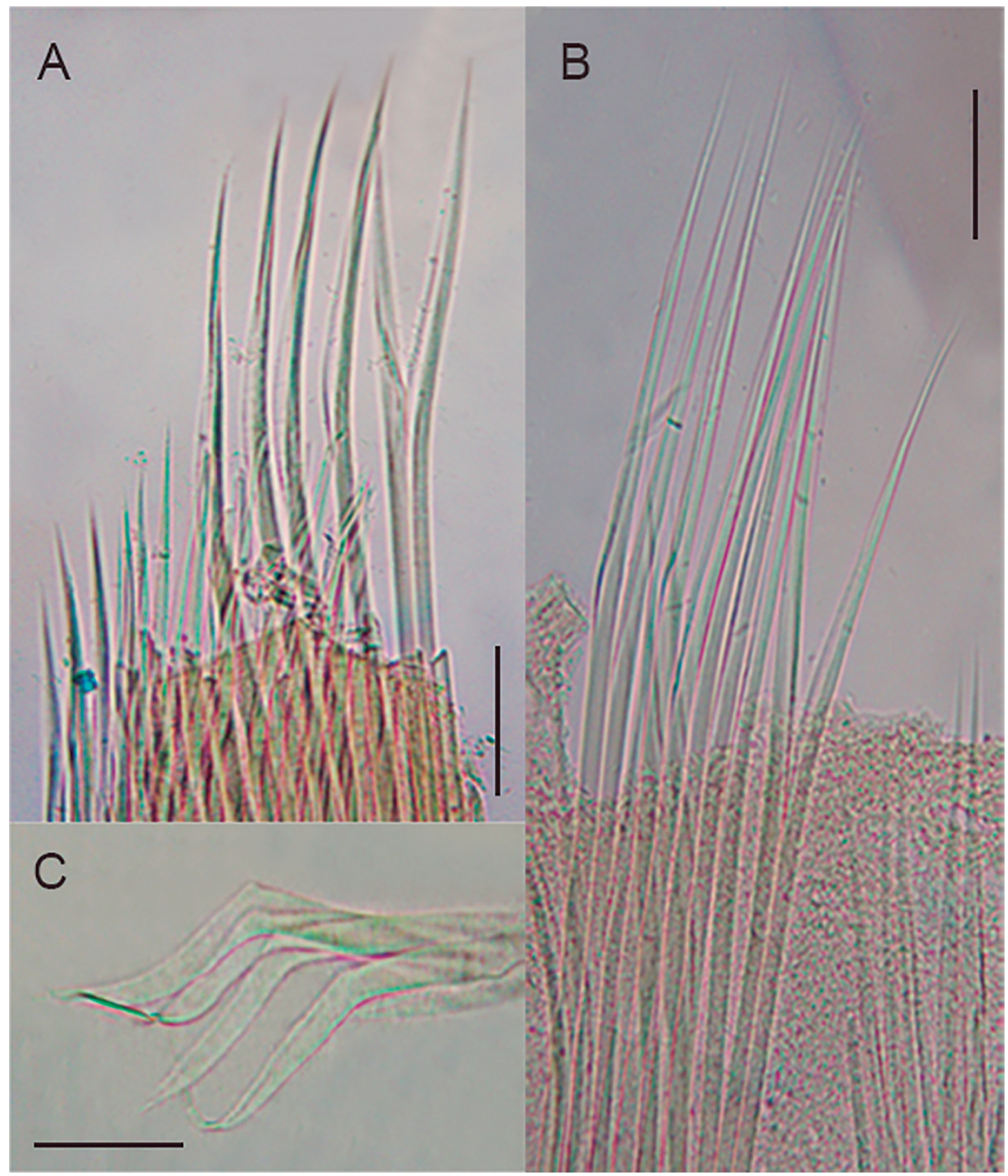

Figure 8. Protula balboensis, types of chaetae. (A) Collar chaetae; limbate chaetae; (B) Thoracic chaetae; limbate chaetae; (C) Abdominal chaetae; geniculate chaetae. Scale bars: A-C: $500 \mu \mathrm{m}$. 
chaetae. Protula balboensis has interradiolar processes on the external face of the radiolar membrane and a rugose tube, whereas $P$. tubularia lacks interradiolar processes and its tube is smooth (i.e., without ridges, peristomes or alveoli) (Monro, 1933; Zibrowius, 1970).

Protula submedia and P. balboensis are quite distinct. Protula submedia produces a tube showing growth lines with peristomes in the anterior section, the number of radioles varies between 25-50, and their abdominal chaetae are straight (Zibrowius, 1970). In contrast, P. balboensis produces a rugose tube (without ridges, peristomes or alveoli), has from 18 to 20 radioles per lobe in large individuals, and its abdominal chaetae are geniculate.

Our specimens have rugose tubes, lacking ridges, peristomes or alveoli, membrane processes are present, the collar and thoracic chaetae are limbate but the abdominal chaetae are geniculate/sickle-shaped. Protula balboensis was described from Balboa on the Pacific coast of Panama. In Brazil, the species was recorded previously at Recife da Lixa, Bahia State, Brazil and, here, we present the first record of this species from Rio de Janeiro State, Sepetiba Bay, in southeastern Brazil.

Habitat: The specimens were found attached to rocks of the intertidal zone and attached under Phragmatopoma sp. aggregate.

Type-locality: Balboa, Pacific Panama.

Distribution: West Pacific Ocean: Japan (Uchida, 1978); West Atlantic Ocean, United States: Jacksonville; Florida; Biscayne Bay, Florida; and Corpus Christi, Texas (BastidaZavala et al., 2017); Gulf of California (Bastida-Zavala, 2008); Pacific Ocean: Mexico (Bastida-Zavala et al., 2016), Acapulco (Bastida-Zavala, 2008), Taboga Island Panama and Gorgona Island (Bastida-Zavala et al., 2016); Colombia (Monro, 1933); Atlantic Ocean: Bocas Del Toro (Bastida-Zavala et al., 2016), Atlantic Panama (BastidaZavala et al., 2016); West Atlantic Ocean, Brazil: Bahia (Zibrowius, 1970) and Rio de Janeiro, Sepetiba Bay (current work).

\section{DISCUSSION}

Lopes (2009) reported eight invasive polychaete species from the Brazilian coast, none of which were serpulids. Later, Rocha et al. (2013) listed 44 non-native polychaete species in Brazil, 10 (22\%) of which were serpulids: F. uschakovi, H. brachyacantha, $H$. dianthus, H. dirampha, $H$. norvegica, Janua brasiliensis (Grube, 1872), Janua pagenstecheri (Quatrefages, 1866), S. minutus, Salmacina incrustans Claparède, 1870 and Salmacina huxleyi (Ehlers, 1887), but J. pagenstecheri is unaccepted, now it named J. heterostropha (Montagu, 1803). From among those species, we also collected specimens of $H$. brachyacantha, $H$. dianthus and $H$. dirampha, thereby expanding their occurrence to northwestern Rio de Janeiro State. These species have also been reported previously in the states of Pernambuco, Bahia (both northeastern Brazil),
São Paulo, Santa Catarina, as well as southeastern Rio de Janeiro. Oricchio et al. (2019) reported two other polychaete species as introduced in Brazil, Branchiomma luctuosum (Grube, 1870) (Sabellidae) and $H$. elegans (Serpulidae). However, two other serpulid species could not be identified in that study, reinforcing the need for experts in taxonomy to assist in studies on introduced species.

One of the problems encountered in compiling lists of introduced species relates to a general lack of detailed knowledge of native species, especially in tropical regions (Junqueira, 2013). Most of the material that Brazilian researchers have access to has come from collection efforts financed by oil companies operating along the Brazilian coast to meet local environmental regulations. However, in order to effectively combat the threats of invasive species, accurate taxonomy is necessary to better define the local fauna (Trebitz et al., 2017). Accurate taxonomic assignments are not always immediately available, especially because of a lack of specialists in taxonomically complex groups, such as the Serpulidae (Lewis et al., 2006; Pyšek et al., 2013; Schwan et al., 2016). Molecular approaches can help to solve this issue, but formal species descriptions using morphological characters are still necessary and some research groups may not have access to expensive and technologically-intensive molecular techniques (ten Hove \& Kupriyanova, 2009; Sun et al., 2016, 2018; Perry et al., 2018).

Bays and estuaries are considered hotspots for species introductions via fouling on ships and the dumping of ballast water (Rocha et al., 2013; Bumbeer \& Rocha, 2016; Ferrario et al., 2017). Recent studies have indicated other possible routes of non-native species introductions. For example, Campbell et al. (2017) reported that floats and plastic ropes used in aquaculture installations can serve as artificial substrates for encrusting organisms, including serpulid polychaetes. Among the water-borne anthropogenic materials that have drawn attention in recent years, plastic is known to act as a vector for non-native species dispersal (Ruiz et al., 1997; Bumbeer \& Rocha, 2016; Campbell et al., 2017).

Zibrowius (1970) pioneered the study of the Serpulidae in Brazil. Subsequent research greatly expanded our knowledge of the diversity and ecology of this group in the southern Atlantic (Nonato \& Luna, 1970; ten Hove, 1975; Rullier \& Amourex, 1979; Silva et al., 1980; Knight-Jones \& Knight-Jones, 1991; Paiva, 1993; SantaIsabel et al., 2000; Nogueira \& ten Hove, 2000; Neves \& Omena, 2003; Winston \& Migotto, 2005; Assis et al., 2008, 2009, 2012; Nogueira \& Abbud, 2009; Skinner et al., 2012; Amaral et al., 2013; Schawn et al., 2016; Vieira et al., 2016). As a result of these efforts, the serpulid fauna in Brazil is known to number 43 species, of which only $14 \%$ are originally described for Brazil and the remaining $86 \%$ are considered exotic species (Amaral et al., 2013; Pagliosa et al., 2014).

Thirty-four species of the genus Spirobranchus are known to occur in subtropical and tropical waters (Pillai, 2009; Perry et al., 2018). In Brazil, the genus is represented by two non-native species, S. minutus and S. giganteus. 
Spirobranchus minutus was described from Acapulco in Mexico (Rioja, 1941) and the first Brazilian specimen was collected from São Sebastião (São Paulo State) and later from Ubatuba, in the same State (Zibrowius, 1970; Amaral et al., 2013). The first Brazilian specimen of S. giganteus collected was from /Fernando de Noronha Island (Zibrowius, 1970), with subsequent specimens collected from the states of Bahia, Alagoas and Rio de Janeiro (Amaral et al., 2013). Skinner et al. (2012) reported new associations of S. giganteus with substrates other than corals at Arraial do Cabo, Rio de Janeiro, but among the photographs presented in that article, one specimen does not correspond to S. giganteus (Skinner et al., 2012: fig. 1D), but rather to S. tetraceros, a mistake previously identified by Perry et al. (2017) and confirmed in the present study.

Species of the genus Spirobranchus present differences in opercular morphology, which is the main identification character of the group. However, intraspecific variation in this character can result in misidentifications or incorrect assignment as new species. Based on our material, we consider four ontogenetic morphotypes, i.e., those with: i) a completely conical operculum with concentric striations; ii) an operculum with three small rudimentary spines; iii) an operculum with three more fully-developed and bifurcated spines; or iv) an operculum with two bifurcated lateral spines and a central well-developed spine (Fig. 3A-D). Such within-species morphological variability has been reported for other species. Szabó (2015) observed differences in operculum development among specimens of S. lamarcki (Quatrefages, 1866), but the present issue is not discussed based on operculum ontogeny (Rodrigues et al., in preparation). Spirobranchus tetraceros was originally identified from Australia, but today is broadly distributed from the IndoPacific region to the Caribbean. This species is considered invasive in some of these localities, e.g., Turkey, in the Mediterranean Sea (Pillai, 2009; Perry et al., 2017). In Brazil, Silva (2008) noted S. tetraceros among the species identified in her study and Skinner et al. (2012) recorded S. tetraceros at Arraial do Cabo. Here, we add the third record of this non-native species in Brazil.

Thirteen species of the genus Hydroides have been identified from along the Brazilian coast (Amaral et al., 2013; Pagliosa et al., 2014; Schawn et al., 2016; Ananias, 2017). Based on the results presented in Schwan et al. (2016) and Amaral et al. (2013), H. elegans and H. dirampha appear to be commonly found in Brazilian port zones. Dispersal of these species within or between localities primarily occurs through encrusting human infrastructure, shipping, plastic rafting, and marine litter (Mangano et al., 2018). Recently, H. dianthus was collected from Arraial do Cabo in Rio de Janeiro State by Sun et al. (2017), with this species also potentially being invasive in port zones. Hydroides dianthus, originally described from Connecticut (USA), has been introduced via anthropogenic transport to China, Europe, Japan, the West Indies and Brazil (Sun et al., 2017). Here, we add the second record of $\mathrm{H}$. dianthus for the Rio de Janeiro State, Brazil.

Of the Serpulidae that do not have opercula, three genera have been recorded from along the Brazilian coast: Salmacina, Filogranella, and Protula (ten Hove \& Kupriyanova, 2009). Protula balboensis was originally described from Balboa (Panama), and it has been found on rocks, dock pillars and breakwaters during low tides at Taboga Island (Panama) and Gorgona Island (Colombia) (Monro, 1933), all in the Pacific Ocean. Thereafter, there was a long gap in reports of this species in any survey, until recently when Ananias (2017) recorded the species in the municipality of São Sebastião (Brazil) where it inhabited subtidal and intertidal zones. Our new record from the southern coast of the Rio de Janeiro State is near the locality explored previously by Ananias (2017) and helps to clarify the distribution of occurrences for this species along the Brazilian coast. However, additional surveys are necessary to fully establish the distributional extent of this species in Brazil.

Morphological similarities among some species of polychaetes, particularly with regard to features such as their calcareous tubes and opercula, as is the case for the Serpulidae, can result in errors of taxonomic identification if they are not analyzed by experts. Incorrect taxonomic assignment can result in specimens being elevated to the status of invasive species when in fact they may be undescribed native species or are simply exhibiting within-population variation.

Here, we present three new records of Serpulidae for the Rio de Janeiro State: S. tetraceros, $H$. dianthus, and $P$. balboensis. Spirobranchus tetraceros was initially recorded as being an invasive in Brazil from the southern coast of Rio de Janeiro, and we confirm its continued occurrence there, representing a good opportunity to follow and manage the spread of this species to nearby areas. Our study contributes to filling the knowledge gap regarding occurrences of these three species along the Brazilian coast and increases the number of non-native polychaete species (Rocha et al., 2013) reported in Brazil to 46. However, we strongly recommend further surveys to assess invasiveness in the Brazilian marine environment.

\section{ACKNOWLEDGMENTS}

We wish to thank Harry ten Hove and Rolando Bastida-Zavala for their help in clarifying our doubts about species and change information several times. We would like to thank Hélio Ricardo da Silva for his review of the MS in the English version. This work was supported by Coordenação de Aperfeiçoamemto de Pessoal de Nível Superior (CAPES) and Conselho Nacional de Desenvolvimento Científico e Tecnológico (CNPq). SISBIO authorization number 11032-5 e 36194-7.

\section{REFERENCES}

Amaral, A.C.Z.; Nallin, S.A.H.; Steiner, T.M.; Forroni, T.O. \& Gomes-Filho, D. 2013. Catálogo dasespécies de Annelida Polychaetado Brasil. Campinas, Unicamp. 83p. http://www.ib.unicamp.br/museu zoologia/files/lab museu zoologia/ Cat\%(3\%A1logo Polychaeta Brasil Amaral et al 2013 1a.pdf. 
Ananias, C.D.N. 2017. Diversidade de Serpulidae (Annelida, Polychaeta) entre as regiões Sul e Nordeste do Brasil. (Masters Dissertation). Universidade de São Paulo, Instituto de Biociencias. DOI

Assis, J.E.; Alonso, C. \& Christoffersen, M.L. 2008. First record of Ficopomatus uschakovi (Pillai, 1960) Serpulidae (Polychaeta: Annelida) for the Western Atlantic. Revista Nordestina de Biologia, 19: 51-58.

Assis, J.E.; Alonso, C.; Brito, R.J.; Santos, A.S. \& Christoffersen, M.L. 2012. Polychaetous Annelids from the coast of Paraíba State, Brazil. Revista Nordestina de Biologia, 21(2): 3-45.

Assis, J.E.; Costa, D.A. \& Christoffersen, M.L. 2009. First Record of Hydroides similoides (Serpulidae: Polychaeta) from Brazil. Marine Biodiversity Records, 2: 1-3. D01

Augener, H. 1906. Reports on the results of dredging, under the supervision of Alexander Agassiz, in the Gulf of Mexico and the Caribbean Sea, and on the east coast of the U.S. 1877-1880, by the U.S.S. Coast Survey Steamer "Blake". XLII, Westindische Polychaeten. Bulletin of the Museum of Comparative Zoology at Harvard College, 43: 91-196.

Augener, H. 1934. Polychaeten aus den Zoologischen Museen von Leiden und Amsterdam. IV Schluss. Zoologische Mededeelingen, 17: 67-160. http:// www.repository.naturalis.nl/document/149757.

Bastida-Zavala, J.R. 2008. Serpulids (Annelida: Polychaeta) from the Eastern Pacific, including a brief mention of Hawaiian serpulids. Zootaxa, 1722: 1-61.

Bastida-Zavala, J.R. 2009. Serpulidae Rafinesque, 1815. In: de LeónGonzález, J.A.; BastidaZavala, J.R.; Carrera-Parra, L.F.; García-Garza, M.E.; Peña-Rivera, A.; Salazar-Vallejo, S.I. \& Solís-Weiss, V. (Eds.). Poliquetos (Annelida: Polychaeta) de México y América Tropical. México, Universidad Autónoma de Nuevo León, Monterrey. pt. 3, p. 521-554.

Bastida-Zavala, J.R. \& García-Madrigal, S. 2012. First record in the Tropical Eastern Pacific of the exotic species Ficopomatus uschakovi (Polychaeta, Serpulidae). ZooKeys, 238: 45-55. DOI

Bastida-Zavala, J.R. \& Salazar-Vallejo, S.I. 2000. Serpúlidos (Polychaeta: Serpulidae) del (aribe noroccidental: Hydroides y Serpula. Revista de Biología Tropical, 48: 841-858.

Bastida-Zavala, J.R. \& ten Hove, H.A. 2002. Revision of Hydroides Gunnerus, 1768 (Polychaeta: Serpulidae) from the Western Atlantic Region. Beaufortia, Amsterdan, 52: 103-173.

Bastida-Zavala, J.R. \& ten Hove, H.A. 2003. Revision of Hydroides Gunnerus, 1768 (Polychaeta: Serpulidae) from the Eastern Pacific Region and Hawaii. Beaufortia, Amsterdan, 53: 67-110.

Bastida-Zavala, J.R.; Cann, L.D.; Mc Keppel, E. \& Ruiz, G.M. 2017. The fouling serpulids (Polychaeta: Serpulidae) from United States coastal waters: an overview. European Journal of Taxonomy, 344: 1-76.

Bastida-Zavala, J.R.; Rodríguez-Buelna, A.S.; de León-González, J.A.; Camacho-Cruz, K.A. \& Carmona, I. 2016. New records of sabellids and serpulids (Polychaeta: Sabellidae, Serpulidae) from the Tropical Eastern Pacific. Zootaxa, 4184(3): 401-457.

Benedict, J.E. 1887. Descriptions of ten species and one new genus of the Annelids from the dredgings of the U.S. Fish Commission Steamer Albatross. Proceedings of the United States National Museum, 9: 547-553.

Ben-Eliahu, M.N. \& ten Hove, H.A. 2011. Serpulidae (Annelida: Polychaeta) from the Suez Canal - From a Lessepsian Migration Perspective (a Monograph). Zootaxa, 2848: 1-147.

Blainville, H. 1818. Mémoire sur la classe des Sétipodes, partie des Vers à sang rouge de M. Cuvier, et des Annélides de M. de Lamarck. Bulletin de la Société Philomatique de Paris, 3: 78-85.

Bumbeer, J. \& Rocha, R.M. 2016. Invading the natural marine substrates: a case study with invertebrates in South Brazil. Zoologia, 33(3): 1-7. e2050211. DOI

Campbell, M.L.; King, S.; Heppenstall, L.D.; van Gool, E.; Martin, R. \& Hewitt, C.L. 2017. Aquaculture and urban marine structures facilitate native and non-indigenous species transfer through generation and accumulation of marine debris. Marine Pollution Bulletin, 123(1-2): 304-312. D0I

Carlton, J.T. 1989. Man's Role in Changing the Face of the Ocean: Biological Invasions and Implications for Conservation of Near-Shore Environments. Conservation Biology, 3(3): 265-273. DOI

Castro, M.C.T.; Fileman, T.W. \& Hall-Spencer, J.M. 2017. Invasive species in the Northeastern and Southwestern Atlantic Ocean: A review. Marine Pollution Bulletin, 116: 41-47. DOI

Çinar, M.E. 2013. Alien polychaete species worldwide: current status and their impacts. Journal of the Marine Biological Association of the United Kingdom, 93(5): 1257-1278. DOI

Claparède, E. 1870. Les Annélides Chétopodes du Golfe de Naples. Annélides Sédentaires. Supplément. Mémoires de la Société de Physique et d'Historie Naturelle de Genève, 20(2): 365-542. http://biodiversitylibrary.org/ page/2094031.

Clarke, C.; Hilliard, H.; Junqueira, A.O.R.; Leal-Neto, A.C.; Polglaze, J. \& Raaymakers, S. 2004. Ballast water risk assessment, Port of Sepetiba, Federal Republic of Brazil: Final Report. Perth, URS. 131p. (GloBallast Monograph Series, 14).

Corriero, G.; Pierri, C. \& Accoroni, S. 2016. Ecosystem vulnerability to alien and invasive species: a case study on marine habitats along the Italian coast. Aquatic Conservation, 409: 392-409.

Dauvin, J.C.; Dewarumez, J.M. \& Gentil, F. 2003. Liste actualisée dês espèces d'Annélides Polychètes présents en Manche. Cahiers de Biologie Marine, 44: 67-95.

Ehlers, E. 1887. Reports on the results of dredging, under the direction of L.F. Pourtalès, during the years 1868-1870, and of Alexander Agassiz, in the Gulf of Mexico (1877-78), and in the Caribbean Sea (1878-79), in the U.S. Coast Survey steamer "Blake", Lieut-Com. C.D. Sigsbee, U.S.N. and Commander J.R. Bartlett, U.S.N., commanding. XXXI. Report on the annelids. Memoirs of the Museum of Comparative Zoology at Harvard College, 15: 1-355. https://www.biodiversitylibrary.org/ item/96641\#page/7/mode/1up.

Ferrario, J.; Caronni, S.; Occhipinti-Ambrogi, A. \& Marchini, A. 2017. Role of commercial harbours and recreational marinas in the spread of nonindigenous fouling species. Biofouling, 33(8): 651-660. https://www. ncbi.nlm.nih.gov/pubmed/28786306.

Fitzhugh, K. 1989. A systematic revision of the Sabellidae-CaobangiidaeSabellongidae complex (Annelida: Polychaeta). Bulletin of the American Museum of Natural History, 192: 1-104.

Gracia, A.C.; Rangel-Buitrago, N. \& Flórez, P. 2018. Beach litter and woodydebris colonizers on the Atlantic department Caribbean coastline, Colombia. Marine Pollution Bulletin, 128: 185-196.

Grube, A.E. 1870. Beschreibungen neuer oder weniger bekannter von Hrn. Ehrenberg gesammelter Anneliden des rothen Meeres. Monatsbericht der Koniglich Preussischer Akademie der Wissenschaften zu Berlin, 1869: 484-521. http://www.biodiversitylibrary.org/page/36276705.

Grube, A.E. 1872. Zur kritischen Übersicht der bisher beschriebenen Terebellen und über Terebellides anguicomus und einige Serpulaceen. JahresBericht der Schlesischen Gesellschaft für vaterländische Cultur, 49: 48-53.

Gündoğdu, S.; Çevik, C. \& Karaca, S. 2017. Fouling assemblage of benthic plastic debris collected from Mersin Bay, NE Levantine coast of Turkey. Marine Pollution Bulletin, 124(1): 147-154.

Gunnerus, J.E. 1768. Om nogle Norske Coraller. Det Kongelige Norske Videnskabens Selskab Skrifter, 4: 38-73.

Haswell, W.A. 1883. On some new Australian tubicolous Annelids. Proceedings of the Linnean Society of New South Wales, 7: 633-638.

Junqueira, A.O.R. 2013. Guilty or innocent? The need to improve the assessment of impacts caused by non-native species. Aquatic Conservation Marine Freshwater Ecosystem, 23: 641-645. 
Kauano, R.V.; Roper, J.J. \& Rocha, R.M. 2017. Small boats as vectors of marine inavasion: experimental test of velocity and desiccation as limits. Marine Biology, 164: 27.

Kiessling, T.; Gutow, L. \& Thiel, M. 2015. Marine Litter as Habitat and Dispersal Vector. In: Bergmann, M., Gutow, L. \& Klages, M. (Eds.). Marine Anthropogenic Litter. New York Springer. p. 141-180.

Kinberg, J.G.H. 1867. Annulata nova. Öfversigt af Kunglige Vetenskabsakademiens Stockholm, Föhrhandlingar, 23: 337-357. http:// biodiversitylibrary.org/page/32287795.

Knight-Jones, P. \& Knight-Jones, E.W. 1991. Ecology and distribution of Serpuloidea (Polychaeta) round South America. Ophelia 5, (Suppl.): 579-586. (Proceedings of the Second International Polychaete Conference)

Krantz, G.W. 1978. A Manual of Acarology. Field Guide and Catalogues. 2. ed. Corvallis, Oregon State University Book. 509p.

Kupriyanova, E.; Sun, Y.; Hove, H.A.T.; Wong, E. \& Rouse, G.W. 2015. Serpulidae (Annelida) of Lizard Island, Great Barrier Reef, Australia. Zootaxa, 4019(1): 275

Leal-Neto, A.C. \& Jablonski, S. 2004. 0 Programa GloBallast no Brasil. In: Silva, J.S.V. \& Souza, R.C.C. (Eds.). Água de lastro e bioinvasão. Rio de Janeiro, Editora Interciência. p. 11-20.

Lewis, J.A.; Watson, C. \& ten Hove, H.A. 2006. Establishment of the Caribbean serpulid tubeworm Hydroides sanctaecrucis Krøyer [in] Mörch, 1863 in northern Australia. Biological Invasions, 8: 665-671. DOI

Link, H.; Nishi, E.;Tanaka, K.; Bastida-Zavala, J.R.; Kupriyanova, E.K. \& Yamakita, T. 2009. Hydroides dianthus (Polychaeta: Serpulidae), an alien species introduced into Tokyo Bay, Japan. Biodiversity Records, 6430: 1-6. D0I

Linnaeus, C. 1758. Systema Naturae per regna tria naturae, secundum classes, ordines, genera, species, cum characteribus, differentiis, synonymis, locis. Holmiae, Laurentius Salvius. 824p.

Lopes, R.M. 2009. Informe sobre as espécies exóticas invasoras marinhas no Brasil. Brasília, Ministério do Meio Ambiente.

Mangano, M.C.; Ape, F. \& Mirto, S. 2018. The role of two non-indigenous serpulid tube worms in shapping artificial hard substrata communities: Case study of a fish farm in the central Mediterranean Sea. Aquaculture Environment Interactions, 11: 41-51. D01

Marchini, A.; Ferrario, J.; Sfriso, A. \& Occhipinti-Ambrogi, A. 2015. Current status and trends of biological invasions in the Lagoon of Venice, a hotspot of marine NIS introductions in the Mediterranean Sea. Biological Invasions, 17(10): 2943-2962. DOI

Monro, C.C.A. 1933. The Polychaeta Sedentaria collected by Dr C. Crossland at Colon in the Panama region and the Galapagos Islands during the expedition of the S.Y. St. George. Proceedings of the Zoological Society of London, 103(4): 1039-1092.

Montagu, G. 1803. Testacea Britannica or Natural History of British Shells, Marine, Land, and Fresh-water, Including the most Minute: Systematically Arranged and Embellished with Figures. J. White, London, two volumes.

Mörch, 0.A.L. 1863. Revisio critica Serpulidarum. Et bidrag til rørormenes naturhistorie. Naturhistorisk Tidsskrift, Series, 3(1): 347-470.

Neves, C.S. \& Rocha, R.M. 2008. Introduced and cryptogenic species and their management in Paranaguá Bay, Brazil. Brazilian Archives of Biology and Technology, 51: 623-633.

Neves, G. \& Omena, E. 2003. Influence of sponge morphology on the composition of the polychaete associated fauna from Rocas Atoll, northeast Brazil. Coral Reefs, 22: 123-129.

Nogueira, J.M.M. \& Abbud, A. 2009. Three new serpulids (Polychaeta: Serpulidae) from the Brazilian Exclusive Economic Zone. Zoosymposia, 2: 201-227.

Nogueira, J.M.M. \& ten Hove, H.A. 2000. On a new species of Salmacina Claparède, 1870 (Polychaeta: Serpulidae) from São Paulo State, southeastern Brazil. Beaufortia, Amsterdam, 50: 151-162.
Nonato, E.F. \& Luna, J.A.C. 1970. Anelídeos poliquetas do nordeste do Brasil. I - Poliquetas bentônicos da costa de Alagoas e Sergipe. Boletim do Instituto Oceanográfico, Universidade de São Paulo, 19: 57-130.

Oricchio, F.T.; Marques, A.C.; Hajdu, E.; Pitombo, F.B.; Azevedo, F.; Passos, F.D.; Vieira, L.M.; Stampar, S.N.; Rocha, R.M. \& Dias, G.M. 2019. Exotic species dominate marinas between the two most populated regions in the southwestern Atlantic Ocean. Marine Pollution Bulletin, 146: 884-892.

Otani, M. \& Yamanishi, R. 2010. Distribution of the alien species Hydroides dianthus (Verrill, 1873) (Polychaeta: Serpulidae) in Osaka Bay, Japan, with comments on the factors limiting its invasion. Plankton and Benthos Research, 5(2): 62-68.

Pagliosa, P.R.; Doria, J.G.; Misturini, D.; Otegui, M.B.P.; Oortman, M.S.; Weis, W.A.; Faroni-Perez, L.; Alves, A.P.; Camargo, M.G.; Amaral, A.C.Z.; Marques, A.C. \& Lana, P.C. 2014. NONATObase: a database for Polychaeta (Annelida) from the Southwestern Atlantic Ocean. Database.

Paiva, P.C. 1993. Trophic structure of a shelf polychaete taxocoenosis in southern Brazil. Cahiers de Biologie Marine, 35: 39-55.

Pallas, P.S. 1766. Miscellanea Zoologica. Hagae Comitum, 224p. https://www. biodiversitylibrary.org/item/138853\#page/8/mode/1up.

Pelletier-Rousseau, M.; Bernier, R.; Clarke Murray, C.; Drolet, D.; LacoursièreRoussel, A.; Locke, A.; Martin, J.L.; McKenzie, C.H.; McKindsey, C.W.; Therriault, T.W. \& Simard, N. 2019. Assessment of recreational boating as a vector for marine non-indigenous species on the Atlantic coast of Canada. Biological invasions, 21: 2447-2470.

Perry, 0.; Bronstein, 0.; Simon-Blecher, N.; Atkins, A.; Kupriyanova, E.; ten Hove, H.A.; Levy, 0. \& Fine, M. 2018. On the genus Spirobranchus (Annelida, Serpulidae) from the northern Red Sea, and a description of a new species. Invertebrate Systematics, 32: 605-626.

Perry, 0.; Sapir, Y.; Perry, G.; ten Hove, H.A. \& Fine, M. 2017. Substrate selection of Christmas tree worms (Spirobranchus spp.) in the Gulf of Eilat, Red Sea. Journal of the Marine Biological Association of the United Kingdom, 98(4): 791-799.

Philippi, A. 1844. Einige Bemerkungen über die Gattung Serpula, nebst Aufzählung der von mir im Mittelmeer mit dem Thier beobachteten Arten. Archiv für Naturgeschichte, 10(1): 186-198.

Pillai, T.G. 1960. Some marine and brackish-water serpulid polychaetes from Ceylon, including new genera and species. Ceylon Journal of Science, Biological Sciences, 3: 1-40.

Pillai, T.G. 2009. Description of new serpulid polychaetes from the Kimberleys of Australia and discussion of Australian and Indo-West Pacific species of Spirobranchus and superficially similar taxa. Records of the Australian Museum, 61(2): 93-199.

Pyšek, P.; Hulme, P.E.; Meyerson, L.A.; Smith, G.F.; Boatwright, J.S.; Crouch, N.R.; Figueiredo, E.; Foxcroft, L.C.; Jarosik, V.; Richardson, D.M.; Suda, J. \& Wilson, J.R.U. 2013. Hitting the right target: taxonomic challenges for, and of, plant invasions. AoB Plants, 5: plt. 042. D01

Quatrefages, A. de. 1866. Histoire naturelle des Annelés marins et d'eau douce. Annélides et Géphyriens. Paris, Librarie Encyclopédique de Roret. Tome 2, pt. 2, p. 337-794.

Rafinesque-Schmaltz, C.S. 1815. Analyse de la nature ou tableau de I'Universe et des corps organize. Aux dépens de l'auteur, Palermo, 8: 224p.

Read, G. 2018a. Hydroides dianthus (Verrill, 1873). World Polychaeta database. Available at: http://www.marinespecies.org/aphia. php? $p=$ taxdetails\&id=131000. Access in: 28/12/2018.

Read, G. 2018b. Spirobranchus tetraceros (Schmarda, 1861). World Polychaeta database. Available at: http://www.marinespecies.org/aphia. php?p=taxdetails\&id=131055. Access in: 29/12/2018.

Rioja, E. 1941. Estudios Anelidológicos III. Datos para el conocimiento de la fauna de poliquetos de las costas mexicanas del Pacífico. Anales del Instituto de Biología, 12: 669-746. 
Risso, A. 1826. Histoire Naturelle des principales productions de l'Europe Meridionale et particulièrement de celles des environs de Nice et des Alpes Maritimes. IV, Mollusques, Annélides. Paris, F.G. Levrault Libraire, 439p.

Rocha, R.M.; Vieira, L.M.; Migotto, A.E.; Amaral, A.C.Z.; Ventura, C.R.R.; Serejo, C.S.; Pitombo, F.B.; Santos, K.C.; Simone, L.R.L.; Tavares, M.; Lopes, R.M.; Pinheiro, U. \& Marques, A.C. 2013. The need of more rigorous assessments of marine species introductions: a counter example from the Brazilian coast. Marine Pollution Bulletin, 67: 241-243.

Ruiz, G.M.; Carlton, J.T.; Grosholz, E.D. \& Hines, A.H. 1997. Global Invasions of Marine and Estuarine Habitats by Non-Indigenous Species: Mechanisms, Extent, and Consequences. American Zoologist, 37: 621-632.

Ruiz, G.M.; Fofonoff, P.W.; Carlton, J.M.; Wonham, M.J. \& Hines, A.H. 2000. Invasion of Coastal Marine Communities in North America: Apparent Patterns, Processes, and Biases. Annual Review of Ecology and Systematics, 31(1): 481-53.

Rullier, F. \& Amoureux, L. 1979. Annélides Polychaètes. Annales de l'Institute Océanographique, 55: 145-206.

Santa-Isabel, L.M.; Leão, Z.M.A.N. \& Peso-Aguiar, M.C. 2000. Polychaetes from the Guarajuba coral reefs, Bahia, Brazil. Bulletin of Marine Science, 67(1): 645-653. (Proceedings of the $6^{\circ}$ International Polychaete Conference)

Schmarda, L.K. 1861. Neue wirbellose Thiere beobachtet und gesammelt auf einer Reise um die Erde 1853 bis 1857. Erster Band (zweite Hälfte) Turbellarian, Rotatorien und Anneliden. Leipzig, Wilhelm Engelmann.

Schwan, I.D.S.; Brasil, A.C.D.S.; Neves, D. \& Dias, G.M. 2016. The invasive worm Hydroides elegans (Polychaeta: Serpulidae) in southeastern Brazil and its potential to dominate hard substrata. Marine Biology Research, 12(1): 96-103.

Silva, J.S.V. 2008. Comunidades macrobentônicas de substrato consolidado natural e artificial da Baía de Sepetiba, $R J$, com ênfase na dinâmica de espécies introduzidas. (Doctoral Thesis). Rio de Janeiro, Universidade Federal.

Silva, S.H.G.; Nunes, A.J.B.; Alves, M.C.S. \& Lage, V.A. 1980. Contribuição ao estudo das comunidades incrustantes que ocorrem na Baía da Guanabara, Rio de Janeiro, Brasil. Resultados preliminares. Revista Brasileira de Biologia, 40(2): 367-382.

Skinner, L.F.; Barboza, D.F. \& Rocha, R.M. 2016. Rapid Assessment Survey of introduced ascidians in a region with many marinas in the southwest Atlantic Ocean, Brazil. Management of Biological Invasions, 7(1): 13-20.

Skinner, L.F.; Tenório, A.A.; Penha, F.L. \& Soares, D.C. 2012. First record of Spirobranchus giganteus (Pallas, 1766) (Polychaeta, Serpulidae) on southeastern Brazillian coast: new biofouler and free to live without corals? Pan-American Journal of Aquatic Sciences, 7: 117-124.

Sun, Y.; ten Hove, H.A. \& Qiu, J.W. 2012. Serpulid polychaetes from Hong Kong. Zootaxa, 3424: 1-42.

Sun, Y.; Wong, E.; Ahyong, S.T.; Williamsonb, J.E.; Hutchings, P.A. \& Kupriyanova, E. 2018. Barcoding and multi-locus phylogeography of the globally distributed calcareous tubeworm genus Hydroides Gunnerus, 1768 (Annelida, Polychaeta, Serpulidae). Molecular Phylogenetics and Evolution, 127: 732-745.

Sun, Y.; Wong, E.; Keppel, E.; Williamson, J. \& Kupriyanova, E. 2017. A global invader or a complex of regionally distributed species? Clarifying the status of an invasive calcareous tubeworm Hydroides dianthus (Verrill, 1873) using barcoding. Marine Biology, 164: 28.

Sun, Y.; Wong, E.; ten Hove, H.A.; Hutchings, P.A.; Williamson, J.E. \& Kupriyanova, E.K. 2015. Revision of the genus Hydroides (Annelida: Serpulidae) from Australia. Zootaxa, 1009(1): 001-099.

Sun, Y.; Wong, E.; Tovar-Hernández, M.A.; Williamson, J.E. \& Kupriyanova, E.K. 2016. Is Hydroides brachyacantha (Serpulidae: Annelida) a widespread species? Invertebrate Systematics, 30(1): 41-59.
Szabó, R. 2015. Regeneration and Calcification in the Spirobranchus lamarcki operculum: development and comparative genetics of a novel appendage. (Doctoral Thesis). University of St Andrews, Scotland.

ten Hove, H.A. 1970. Serpulinae (Polychaeta) from the Caribbean: I - The genus Spirobranchus. Studies on the Fauna of Curaçao and other Caribbean Islands, 32: 1-57.

ten Hove, H.A. 1975. Serpulinae (Polychaeta) from the Caribbean: III The genus Pseudovermilia. Studies on the Fauna of Curaçao and other Caribbean Islands, 47(156): 46-101.

ten Hove, H.A. \& Kupriyanova, E.K. 2009. Taxonomy of Serpulidae (Annelida, Polychaeta): The state of affairs. Zootaxa, 2036: 1-126.

Treadwell, A.L. 1902. The polychaetous annelids of Porto Rico. Bulletin of the United States Fish Commission, 2: 181-210.

Trebitz, A.S.; Hoffman, J.C.; Darling, J.A.; Pilgrim, E.M.; Kelly, J.R.; Brown, E.M.; Chadderton, W.L.; Egan, S.P.; Grey, E.K.; Hashsham, S.A.; Klymus, K.E.; Mahon, A.R.; Ram, J.L.; Schultz, M.T.; Stepien, C.A. \& Schardt, J.C. 2017. Early detection monitoring for aquatic non-indigenous species: Optimizing surveillance, incorporating advanced technologies, and identifying research needs. Journal of Environmental Management, 202(1): 299-310.

Tricarico, E.; Junqueira, A.O.R. \& Dudgeon, D. 2016. Alien species in aquatic environments: a selective comparison of coastal and inland waters in tropical and temperate latitudes. Aquatic Conservation Marine and Freshwater Ecosystems, 26: 872-891. DOI

Trott, T.J. 2004. Cobscook Bay Inventory: A Historical Checklist of Marine Invertebrates Spanning 162 Years. Northeastern Naturalist, 11(Special issue 2): 261-324.

Uchida, H. 1978. Serpulid tube worms (Polychaeta, Sedentaria) from Japan with the systematic review of the group. Bulletin Marine Park Research Stations, 2(1/2): 1-98.

Verrill, A.E. 1873. Report upon the invertebrate animals of Vineyard sound and the adjacent waters, with an account of the physical characters of the region. Report of the United States Commission for Fisheries, 1: 295-778.

Vieira, E.A.; Dias, G.M. \& Flores, A.A. 2016. Effects of predation depend on successional stage and recruitment rate in shallow benthic assemblages of the Southwestern Atlantic. Marine Biology, 163(4): 1-12.

Winston, J.E. \& Migotto, A.E. 2005. A new encrusting interstitial marine fauna from Brazil. Invertebrate Biology, 124(1): 79-87.

Wong, E.; Kupriyanova, E.K.; Hutchings, P.; Capa, M.; Radashevsky, V.I. \& ten Hove, H. 2014. A graphically illustrated glossary of polychaete terminology: invasive species of Sabellidae, Serpulidae and Spionidae. Memoirs of Museum Victoria, 71: 327-342.

Zenetos, A.; Çinar, M.; Pancucci, A.; Harmelin, J.; Furnari, G.; Andaloro, F.; Bellou, N.; Streftaris, N. \& Zibrowius, H. 2005. Annotated list of marine alien species in the Mediterranean with records of the worst invasive species. Mediterranean Marine Science, 6: 63-118. D0I

Zenetos, A.; Gofas, S.; Verlaque, M.; Çinar, M.; García Raso, J.; Bianchi, C.; Morri, C.; Azzurro, E.; Bilecenoglu, M.; Froglia, C.; Siouku-Frangou, I.; Violanti, D.; Sfriso, A.; Giangrande, A.; Katagan, T.; Ballesteros, E.; Ramos-Espla, A.A.; Mastrototaro, F.; Ocana, 0.; Zingone, A.; Gambi, M.C. \& Streftaris, N. 2010. Alien species in the Mediterranean MSFD areas by 2010. A contribution to the application of European Union's Marine Strategy Framework Directive (MSFD). Part I. Spatial distribution. Mediterranean Marine Science, 11(2): 381-493.

Zibrowius, H. 1970. Contribution à l'étude des Serpulidae (Polychaeta Sedentaria) du Brésil. Boletim do Instituto Oceanográfico, Universidade de São Paulo, 19: 1-32.

Zibrowius, H. 1983. Nouvelles données sur la distribution de quelques Scléractiniaires'méditerranéens' a l'est et a l'ouest du détroit de Gibraltar. Rapports et Procès-verbaux des Réunions de la Commission Internationale pour l'Exploration Scientifique de la Mer Méditerranée, 28: 307-309. 